\title{
Genetiği Değiştirilmiş Organizmalara (GDO) İlişkin Avrupa Birliği'ndeki Yasal Düzenlemeler
}

\author{
ZEHRA GIZEM ATEŞ \\ av.zehra@yahoo.com.tr \\ ORCID ID: 0000-0002-3973-8630
}

\begin{abstract}
Öz: Genetiği değiştirilmiş organizma (GDO), doğal olmayan yollarla bir canlıya gen aktarılarak DNA yapısının değiştirilmesi ile oluşan yeni organizmaya verilen addır. GDO'lar modern biyoteknolojik çalışmalar ile elde edilmektedir. Ancak bunların insan sağlı̆̆ı için önemli riskleri olduğu bilinmektedir. AB'de 1993 yılında yürürlüğe giren Maastricht Anlaşması ile GDO’ların sahip olduğu sağlik risklerine karşı yasal düzenlemeler yapılması gerektiği kabul edilmiştir. Buna bağlı olarak AB hukukunda GDO’larla ilgili birçok yönerge ve tüzük kabul edilmiştir.
\end{abstract}

Anahtar Kelimeler: Genetiği değiștirilmiş organizma, Sağlık riskleri, Avrupa Birliği yönergeleri.

\section{Giriș}

Bir canlının gen diziliminin biyoteknolojik gelişmeler sayesinde değiştirilmesi ile elde edilen genetiği değiştirilmiş organizmalar, son yıllarda yaşanan biyoteknolojik gelişmeler neticesinde ortaya çıkan, üzerinde çokça durulan ve tartışılan bir konu haline gelmiştir. Gün geçtikçe dünya nüfusunun artması, bunun yanında su kaynaklarının, verimli toprakların azalması sonucunda insanlar ileriki yıllarda su ve yiyecek kıtlı̆̆ yaşanacağ ${ }_{1}$ kaygısı içine girmişlerdir. Ortalama olarak 2050 yıllarında dünyada çok ciddi boyutlarda açlık ve su sıkıntısı olabileceği tahmin edilmektedir. İște bu sorunlara çözüm olması amacıyla genetiği değiştirilmiş organizmalar üzerinde çalışılmaktadır.

Genetiği değiştirilmiş organizmaların insan, hayvan, bitki sağlı̆̆ı ile çevre ve biyoçeşitlilik üzerinde yaratacağı etkiler hakkında dünyada farkındalığın oluşması ile özellikle AB ülkelerinde yasal düzenlemeler yapılmış ve devletlere bu düzenlemeleri iç hukuklarına dahil etme yükümlülüğü getirilmiştir. İlk olarak dünyada çevreyi koruma bilinci 1972 yllında düzenlenen Stockholm Bildirgesi ile oluşmaya başlamıştır. Daha sonra 1992'de imzaya açılan BM Biyoçeşitlilik Sözleşmesi ve devamı niteliğinde olan Cartagena Biyogüvenlik Protokolü ile devletlere yasal düzenleme

* Dr., İstanbul Kültür Üniversitesi, Lisansüstü Eğitim Enstitüsü. 
yapma yükümlülüğü getirilmiştir.

Genetiği değiştitilmiş organizma (GDO) "modern biyoteknolojik yöntemler kullanılmak suretiyle gen aktarılarak elde edilmiş insan dışındaki canlı organizma" olarak tanımlanmaktadır. ${ }^{1}$

Dünya Sağlık Örgütü tarafından yapılan tanımlamaya göre GDO, genetik yapıları doğal olmayan yollarla değiştirilmiş organizmalardır. ${ }^{2}$ Ayrıca Avrupa Birliğìinin konuyla ilgili 2001/18/EC sayılı yönergesine göre GDO, insan hariç olmak üzere doğal yolla gerçekleşmeyecek bir şekilde genetik materyali değiştirilmiş canlı (bitki, hayvan, bakteri vs.) olarak tanımlanmaktadır. ${ }^{3}$

Öğretide ise yukarıdakilere benzer tanımlamalar yapılmaktadır. Genel olarak öğretide genetik yapısı değiştirilmiş organizmalar, biyoteknolojik uygulamalarla bir canlıya başka bir canlıdan gen aktarılması ve bunun sonucunda aktarılan canlının gen yapısının değiştirilmesi, yeni genetik yapıya sahip organizma elde edilmesi şeklinde tanımlanmaktadır. ${ }^{4}$ Bilindiği gibi her canlının temel yapısını DNA oluşturmaktadır. Genetiği değiştirilmiş organizma elde edebilmek için yapılan çalışma, canlıya dışarıdan başka bir canlının DNA’sı nakledilerek tamamen yeni bir DNA dizilimine sahip farklı bir organizma elde edilmesidir. İşte bu yolla meydana gelen yeni genetik özellikler taşıyan hayvanlara "transgenik hayvanlar", bitkilere ise "transgenik bitkiler" denilmektedir. ${ }^{5}$

1983 yılında Monsanto ve Agrigenetics şirketleri tarafından ilk deneysel gen aktarımı ABD’de gerçekleştirilmiştir. ${ }^{6}$ İlk uzun raf ömürlü flavr savr adlı domates 1994 yılının Mayıs ayında ABD'de Food and Drug Administration (FDA) tarafindan piyasaya sürülerek GDO'lu ürün ticareti başlatılmıştır. ${ }^{7}$ Bundan sonra da gen nakli yöntemiyle kuraklığa, aşırı soğuğa, bitki zararlılarına karşı dayanıklı soya, mısır, pamuk, kanola

15977 sayılı Biyogüvenlik Kanunu, md. 2/i, 26.03.2010 tarihli 27533 sayılı Resmi Gazetede yayımlanarak 26.09.2010 tarihinde yürürlüğe girmiştir, erişim 16 Ocak, 2020, https://www.corpus.com.tr/\#!/Yasalar,.

2 World Health Organization (WHO), erişim 19 Ocak, 2020, http://who.int.

3 “2001/18/EC, Art. 2", erişim 19 Ocak, 2020, https://eur-lex.europa.eu/resource.html?uri=cellar:303dd4fa-07a84d20-86a8-0baaf0518d22.0004.02/DOC_1\&format=PDF.

4 M. Ahmet Güneş, "Genetiği Değiştirilmiş Organizmalar ve Çevre Hukuku - Uluslararası Düzenlemeler, Avrupa Birliği Hukuku ve Türkiyedeki Mevcut Durum”, İ̈HHFD, 66/2 (2008), s.49; Özge Özgen Arun, Karlo Muratoğlu ve Funda Yılmaz Eker, "Genetiği Değiştirilmiş Organizmalar Kavramına Genel Bakış", İstanbul Üniversitesi Veteriner Fakültesi Dergisi, 41/1 (2015), s.113, https://www.researchgate.net/publication/271208683 Genetigi_Degistirilmis_Organizmalar_Kavramina_Genel_Bakis (erişim 19.01.2020); Selim Çetiner, "Genetiği Değiştirilmiş Organizma Nedir? Sorular ve Yanıtlar 1-2”, s.1, http://research.sabanciuniv. edu/_ Organizma_ (GDO)_Nedir_Sor_I.pdf. (erişim 19.01.2020); Muzaffer Denli, Genetiği Değiştirilmiş Organizmalar (GDO), İstanbul: İstanbul Ticaret Odası, 2012, s.21; Kemal Özer, Deccal Tabakta, İstanbul: Hayy Kitap, 2010, s.16.

5 Denli, Genetiği Değiştirilmiş, s.21; Çetiner, “Genetiği Değiştirilmiş”, s.1; Güneş, “Genetiği Değiştirilmiş”, s.49; Funda Yılmaz, “Bitkisel Üretimde Genetiği Değiştirilmiş Organizmalar ve Ürünleri ile Biyogüvenlik”, Uzmanlık Tezi, T.C. Kalkınma Bakanlığı, 2014, s.17; Şebnem Mutlu, "Piyasada Satışa Sürülen Cips ve Gevreklerde GDO Varlığının Araştırılması”, Yüksek Lisans Tezi, Namık Kemal Üniversitesi, 2006, s.4.

6 Şeminur Topal, Biyogüvenlik ve Biyoteknoloji, İstanbul: Cem Ofset Matbaası, 2006, s.8.

7 Tecer Atsan ve Tuğba Ekrem Kaya, "Genetiği Değiştirilmiş Organizmaların (GDO) Tarım ve İnsan Sağlığı Üzerine Etkileri”, Uludağ Üniversitesi Ziraat Fakültesi Dergisi, 22/2 (2008), s.3; Yılmaz, "Bitkisel Üretimde”, s.19; Martin Teitel ve Kimberly Wilson, Genetically Engineered Food, Changing the Nature of Nature, Canada: Park Street Press, 1999, s.20; Daniel Charles, Lords of the Harvest, New York: Basic Books, 2002, s.322. 
elde edilmiştir. ${ }^{8}$

\section{GDO’nun Potansiyel Yararları}

Bilim adamları genel olarak genetik mühendisliğinin insan sağlı̆̆ına doğrudan ya da dolaylı faydaları olduğunu düşünmektedirler. ${ }^{9}$ Bununla birlikte GDO’ların potansiyel yararları ve zararları halen tartışılmaktadır. Hatta GDO'ların yararları ve zararlarının derecesi de bilimsel açıdan netlik kazanmadığı için bunlar "potansiyel" yarar ve zararlar olarak anılmaktadır.

Bugün dünyada 1 milyon insan açlık ve yetersiz beslenme ile savaşmaktadır. ${ }^{10} \mathrm{Bu}$ sayı gün geçtikçe artmaktadır. Biyoteknoloji İnovasyon Örgütü’ne (Biotechnology Innovation Organization) göre 2000'lerin başından 2030 yılına kadar dünyadaki mevcut tarım alanlarından iki kat fazla ürün elde edilemezse dünyadaki açlık sorunu önlenemeyecektir. ${ }^{11}$ Örgüte göre yiyecek arzının geleceği biyoteknolojik ürünlerin üretimine bağlıdır. ${ }^{12}$

Son yıllarda dünya nüfusunda aşırı artış nedeniyle tarım alanları, su kaynakları azalmaktadır. 2050 yılında mevcut tarım arazilerinin ve su kaynaklarının 2 milyar insanın ihtiyacını karşılamaya yetmeyeceği ve dünya çapında açlık yaşanacağı tahmin edilmektedir. ${ }^{13}$ İşte bu açlık sorununa çözüm olarak GDO’lu ürünler gösterilmektedir. Genetiği değiştirilmiş tarım ürünleri sayesinde hem açlığa çözüm bulunmuş olacak hem de doğal kaynakların devamlılığı sağlanmış ve biyoçeşitlilik korunmuş olacaktır. ${ }^{14}$

Genetiği değiştirilmiş organizmalar kuraklık, aşırı soğuk, tuzluluk gibi zor koşullarda da yetiştirilebildiğinden düşük maliyetle daha yüksek kalitede ve daha esnek koşullarda yetişen ürünler elde edilecektir. ${ }^{15}$ GDO’lu ürünlerin içeriği vitamin, mineral, protein, karbonhidrat gibi maddeler açısından da zenginleştirildiğinden daha az besin tüketerek insan vücuduna daha fazla fayda sağlanabilecektir. ${ }^{16}$ Böylece

8 Topal, Biyogüvenlik ve Biyoteknoloji, s.8; Yllmaz, "Bitkisel Üretimde", s.19.

9 Robert Evenson ve Terri Raney, The Political Economy of Genetically Modified Foods, USA: Edward Edgar Publishing, 2007, s.61.

10 Kathiann M. Kowalski, The Debate Over Genetically Engineered Food, Healthy or Harmful?, USA: Enslow Publishers, 2002, s.30.

11Food and Agricultural Biotechnology, erişim 19 Ocak, 2020, https://www.bio.org/food-agriculturalbiotechnology.

12 Kowalski, The Debate Over, s.31.

13 Fao (Food And Agriculture Organization Of The United Nations), erişim 19 Ocak, 2020, http://www.fao.org / biotechnology/en/; Yılmaz, "Bitkisel Üretimde", s.28; Denli, Genetiği Değiştirilmiş, s.103; Güneş, "Genetiği Değiştirilmiș”, s.50-51.

14 Roger Krueger, "Ag Biotech: Our Past and Our Future", Genetically Modified Organisms in Agriculture, ed., Gerald C. Nelson, New York: Academic Press, 2001, s.259; Halim Aydın, Sağlıklı Nesiller İçin Önce Sağlıklı Tohum, İstanbul: İstanbul Ticaret Odası Yayınları, 2012, s.83; Evenson ve Raney, The Political Economy, s.66. 15 Aydın, Sağlıklı Nesiller, s.85-87; Güneş, “Genetiği Değiştirilmiş”, s.50; Özlem Oğuzlar, Genetiği Değiştirilmiş Organizmalara İlişkin Uluslararası ve Avrupa Birliği’ndeki Düzenlemeler, İstanbul: Galatasaray Üniversitesi Yayınları, 2009, s.3 vd; Bio technoogy, Economic and Wider Impacts, Organisation For Economic CoOperation and Development (OECD), Paris: 1989, s.26.

16 Evenson ve Raney, The Political Economy, s.61; Denli, Genetiği Değiştirilmiş, s.103; Aydın, Să̆lıkl Nesiller, s.86-87. 
yetersiz beslenmenin de önüne geçilecektir. ${ }^{17}$ Bundan başka alerjik reaksiyona sahip inek sütü, yumurta, buğday, yer fıstığg gibi ürünlerin alerjik proteinlerinin çıkarılması veya yapısının değiştirilmesi ile bu besinlerin alerjik etkileri ortadan kaldırılacaktır. ${ }^{18}$

GDO’ların tarımsal alanda sağladığı ileri sürülen bir diğer faydası da tarım ilaçlarına karşı dayanıklılık sağladığından zirai ilaç kullanımının azalması ${ }^{19}$, toprağın daha az kirlenmesi, topraktaki su kaybının önüne geçilmesi, toprakları sürme gereğinin ortadan kalkması ile karbondioksit salınımını azaltması ve işçilik, mazot maliyetlerini düşürmesidir. ${ }^{20}$ Böylece genetiği değiştirilmiş organizmalar sayesinde tüketicinin ödeyeceği fiyat da düşük olacaktır. ${ }^{21}$ Zirai ilaç kullanımının azalması aynı zamanda çiftçilerin enerjiden ve zamandan da tasarruf etmeleri anlamına gelmektedir. ${ }^{22}$

Bunlardan başka genetiği değiştirilmiş organizmaların insan sağlı̆̆ına katkıları bulunmaktadır. Tarımsal üretimde yararlı böceklerin bitkilerin gelişmesinde önemli bir yeri olduğu bilinmektedir. Ancak bu böcekler tarafından yenilerek zarar verilen ürünler de insan sağlığı açısından sakıncalıdır. ${ }^{23}$ Her ne kadar genetiği değiştirilmiş organizmaların tarımda faydalı olan (böcek gibi) canlılara da zarar verdiği, bunları öldürdüğü ileri sürülse de aslında bunların ölmesi insan sağlı̆̆ı açısından yerindedir. Çünkü bu canlıların yediği, etkilediği tarım ürününün tüketilmesi insan sağlığına zararlidir.

\section{GDO’nun Potansiyel Zararları}

Son yıllarda giderek artan dünya nüfusu, doğal kaynakların hızla tüketilmesi ve genetiği değiştirilmiş organizmaların üretiminin çok büyük bir hızla artması, birçok ülkeye yayılması nedeniyle GDO'ların yaratabileceği olumsuzluklar tartışılır hale gelmiştir. GDO’ların faydaları gibi zararlarının da boyutu henüz kesin olarak bilinememektedir. Bu nedenle dünya çapında zararlarına, insan, hayvan sağlığı ve çevre üzerine etkilerine ilişkin tartışmalar devam etmektedir.

GDO'ların çevre üzerinde yaratabileceği en önemli risk, gen kaçışı nedeniyle biyoçeşitliliğin zarar görmesidir. GDO’ların çevreye bilinçsizce serbest bırakılması sonucunda, dışarıdan aktarılan genler rüzgar, tozlaşma gibi etmenlerle çevreye yayılır ve diğer genetiği değiştirilmemiş bitkilere bulaşarak biyoçeşitliliği bozar. ${ }^{24}$ Polenlerle tohumların yayılması nedeniyle, genetiği değiştirilmiş ürünlerin kalıntılarının

\footnotetext{
17 Mutlu, "Piyasada Satışa”, s.13; Denli, Genetiği Değiştirilmiş, s.104; Kowalski, The Debate Over, s.30-31. 18 Aydın, Sağlıklı Nesiller, s.88; Evenson ve Raney, The Political Economy, s.61.

19 Teitel ve Wilson, Genetically Engineered, s.28; Evenson ve Raney, The Political Economy, s.61.

20Güneş, "Genetiği Değiştirilmiş", s.51; Venhar Çelik ve Dilek Turgut-Balık, "Genetiği Değiştirilmiş Organizmalar (GDO)”, Erciyes Üniversitesi Fen Bilimleri Enstitüsü Dergisi, 23/1-2 (2007), s.18-19, http//www.egecep.org.tr. (erişim 19.01.2020); Çetiner, “GDO Nedir?”, s.9; Aydın, Sağlıkl Nesiller, s.84-85.

21 Gabrielle J. Persley ve James N. Siedow, "Application of Biotechnology to Crops - Benefits and Risks"

Genetically Modified Foods (GMO), ed., Michael Ruse ve David Castle, Newyork: Prometheus Books, 2002, s.225.

22 Krueger, “Ag Biotech", s.259.

23 Krueger, “Ag Biotech", s.259.

24 Persley ve Siedow, "Application of Biotechnology", s.230-231; Yllmaz, "Bitkisel Üretimde", s.29-31; Mutlu, "Piyasada Satışa” s.16, 19; Özgen Arun, Muratoğlu ve Eker, "Genetiği Değiştirilmiş”, s.116-117; Teitel ve Wilson, Genetically Engineered, s.37; Aydın, Sağlıklı Nesiller, s.109.
} 
kilometrelerce uzağa taşınabildiği görülmektedir. ${ }^{25}$ Hatta bu gen kaçışı o kadar etkili olmaktadır ki, genetiği değiştirilmemiş (geleneksel) ürünlerin polenlerinin tamamen yok olmasından endişe edilmektedir. ${ }^{26}$

Gen kaçışını engellemek ve etkilerini gidermek için geleneksel tarım yapan çiftçinin ürününü yetiştirme veya depolama, nakil sırasında önlem alması gerekmektedir. ${ }^{27}$ $\mathrm{Bu}$ önlemler de üreticiye fazladan maliyet yüklemektedir. Bundan başka gen kaçışı nedeniyle tüm ekosistem, insan ve hayvan sağllğı olumsuz etkilenebilir. GDO'lu ürünlerden geleneksel ürünlere gen kaçışı sonucunda geleneksel ürünler de kendilerine has özelliklerini kaybedeceğinden bunların etiketlenmesi dahi tüketicinin gıdaya ilişkin bilgilendirilmesine yetmeyecektir. Dolayısıyla gıda güvenliği, etiketleme, tüketicinin bilgilendirilmesi tartışma konusu haline gelmiştir. ${ }^{28}$

Ayrıca yapılan bazı araştırmalar GDO’ların zirai ilaç kullanımını azaltmadığı tam tersine arttırdığını, hedef olmayan yararlı canlıların ölmesinin tarım ürünlerine zarar verdiğini, gen aktarımının toprağı temizlemek yerine daha çok kirlettiğini göstermektedir. ${ }^{29}$ Hedef olmayan canlıların ölmesi tarım ürünlerinin çoğalmasını engelleyeceği gibi, tarım zehirlerini yemiş böcekleri yiyen kuşlar da bu zehirlerden etkilenmektedir. ${ }^{30}$ Böylece sadece tarım ürünleri değil hayvanlar da dahil olmak üzere ekosistem tarım zehirlerinden olumsuz etkilenmektedir. Sistemin kendi kendini tolere etmesi de uzun yllar almaktadır. ${ }^{31}$ Hedef olmayan türlerin zarar görmesi konusunda bilim adamları görüş birliği içinde olmasa da her bir doğa olayının ayrı ayrı değerlendirilmesi gerektiği ve bundan sonra yapılacak GDO salınımlarının incelenmesi gerektiği konusunda uzlaşmaktadırlar. ${ }^{32}$

GDO’ların insan sağllğı üzerinde yaratabileceği zararlar antibiyotik direnci ve alerjidir. ${ }^{33}$ Üstelik bilim adamları antibiyotik direnci yaratan genin hayvanlardan insanlara geçeceğini belirtiyorlar. ${ }^{34}$ Bilimsel olarak kanıtlanmamıs olmakla birlikte genetiği değiştirilmiş organizmaların antibiyotik direnci yarattı̆̆ı bilinmektedir. ${ }^{35}$ Bir canlıdan diğerine gen aktarılırken alerji riski de bu aktarımla birlikte geçebilir ve bu risklerin piyasaya sürülmeden önce değerlendirilmesi ve tanımlanması gerekmektedir. ${ }^{36}$ Ancak alerji potansiyelinin önceden tahmin edilmesini sağlayacak

25 Anthony Treawas, "Much Food, Many Problems", Genetically Modified Foods, ed., Michael Ruse, David Castle, New York: Prometheus Books, 2002, s.337.

26 Teitel ve Wilson, Genetically Engineered, s.36-37.

27 Kenan Demirkol, GDO: Çă̆daş Esaret, İstanbul: Kaynak Yayınları, 2010, s.72-73; Yılmaz, "Bitkisel

Üretimde", s.37.

28 Mutlu, "Piyasada Satışa" s.15-17; Yılmaz, "Bitkisel Üretimde”, s.39; Özgen Arun, Muratoğlu ve Eker,

"Genetiği Değiştirilmiş", s.117-118; Aydın, Sağlıklı Nesiller, s.104.

29 Demirkol, GDO: Çă̆daş, 63-66; Yılmaz, "Bitkisel Üretimde”, s.31-32.

30 Persley ve Siedow, "Application of Biotechnology", s.230-231; Kowalski, The Debate Over, s.40.

31 Kowalski, The Debate Over, s.40-42.

32 Evenson ve Raney, The Political Economy, s.66.

33 Yılmaz, "Bitkisel Üretimde”, s.33; Mutlu, "Piyasada Satışa”, s.16-18; Özgen Arun, Muratoğlu ve Eker,

"Genetiği Değiştirilmiş", s.11; Aydın, Sağlıklı Nesiller, s.104-105.

34 Özer, Deccal Tabakta, s.221.

35 Teitel ve Wilson, Genetically Engineered, s.37-38; Persley ve Siedow, "Application of Biotechnology", s.230.

36 Persley ve Siedow, "Application of Biotechnology", s.230. 
güvenilir bir metodun olmadığı belirtilmektedir. ${ }^{37}$ Genetik mühendisliği gıdalarında beklenmedik toksinler ve alerji yapııı maddeler ortaya çıkmış ve bunlar Üçüncü Dünya ülkelerinde pazarlanmaktadır. ${ }^{38}$

Genetiği değiştirilmiş organizmaların kullanımında temel teşkil eden ihtiyat ilkesi önceden önlem alınmasını gerektirmektedir. Daha açık bir ifadeyle genetiği değiştirişmiş ürünler pazarlanmadan önce (maliyetleri artıracak olsa da) insan sağlığına verebileceği zararlar araştırılmalıdır. ${ }^{39}$ Henüz kesinleşmemekle birlikte araştırmalara göre ileri sürülen muhtemel riskleri ise kanserojen etki, kısırlık, ölü ve sakat doğumlara yol açmasıdır. ${ }^{40}$

GDO’lu ürünler geleneksel ürünlerden farklı olarak tohum üretmemektedir. Yani GDO'lu ürünler tohum bakımından kısırlaştırılmıştır. Bu nedenle üreticinin her yıl tohum şirketlerinden tohum alması gerekmektedir. GDO'lu ürünlerin tohum ticareti dünya çapında çok büyük bir sektör haline gelmiş ve küresel anlamda bazı şirketlerin tekeline alınmıştır. Her yıl tohum satın almak isteyen üretici belli firmalardan tohumu almak mecburiyetindedir. İşte bu tekelleşme, fiyatların yüksek olması, küçük üreticinin zarar görecek olması nedeniyle GDO’ların sosyo-ekonomik zararı olarak görülmektedir. ${ }^{41}$

Genetiği değiştirilmiş organizmaların açlığa çözüm olacağını ileri süren görüşe karşı bunun mümkün olmadığını, genetik mühendisliğine dayanmak yerine yerli tarımsal biyoçeşitliliği geliştirmenin herkes için daha sağlıklı olacağı ve ancak bu şekilde gida güvenliğinin temin edileceği ileri sürülmektedir. ${ }^{42}$

\section{Avrupa Birliği'nde Genetiği Değiştirilmiş Organizmalara İlişkin Yasal Düzenlemeler Genel Olarak}

Biyoteknoloji alanında yaşanan gelişmeler neticesinde meydana gelebilecek etkiler, GDO’ların insan ve hayvan sağlığı üzerindeki potansiyel riskler taşıyor olması $A B$ üyesi ülkelerde temel yasal düzenleme yapma zorunluluğunu gündeme getirmiştir. 1990'ların başında özellikle son 20 yıldır biyoteknoloji alanında yaşanan gelişmelerin sosyo-ekonomik faydaları, çevre ve insan sağlı̆̆ı üzerindeki potansiyel etkileri $\mathrm{AB}$ üyesi ülkelerde tartışılır olmuştu..$^{43}$ Özellikle ABD'de yaygınlaşan GDO kullanımı, bunların etkileriyle ilgili halk arasındaki endişeleri büsbütün arttırdı ve kamuoyunda güvensizlik baş gösterdi. ${ }^{44}$ Işte bu güvensizliği giderebilmek için GDO'lara ilişkin tek

37 Ronnie Cummins ve Ben Lilliston, Genetically Modified Food, New York: Marlowe \& Company, 2004, s.41. 38 Mae-Wan Ho, Genetik Mühendisliği Rüya mı Kabus mu?, çev., Emral Çakmak, İstanbul: Türkiye İş Bankası Kültür Yayınları, 2001, s.45.

39 Indur M. Goklany, "Applying the Precautionary Principle to Genetically Modified Crops", Genetically Modified Foods, ed., Michael Ruse, David Castle, New York: Prometheus Books, 2002, s.284.

40 Özer, Deccal Tabakta, s.190 vd.; Yllmaz, "Bitkisel Üretimde”, s.33.

41 Mutlu, "Piyasada Satışa”, s.20; Yılmaz, "Bitkisel Üretimde”, s.38.

$42 \mathrm{Ho}$, Genetik Mühendisliği, s.123.

43 Silvia Franceskon, "The New Directive 2001/18/EC on the Deliberate Release Of Genetically Modified Organisms into the Enviroment: Changes and Perspectives", 10/3 (2001), s.309, http://onlinelibrary. wiley.com/doi/10.1111/14679388.00290/epdf?r3_referer=wol\&tracking_action=preview_click\&show_ checkout=1\&purchase_referrer=www.google.com.tr\&purchase_site_license. (erişim 20.01.2020)

44 Franceskon, “The New Directive", s.309. 
düze bir sistem oluşturulmaya başlandı.

Avrupa Birliği’nde 1993 yılında yürürlüğe giren Maastricht Anlaşması ile çevre hukukuna ilişkin yaklaşımlar "çevre politikası" halini aldı ve bu tarihten sonra çevre hukukuna özgü ilkeler yasal düzenlemelerin temelini oluşturmaya başladı. ${ }^{45} \mathrm{Bu}$ anlaşma ile $\mathrm{AB}$ bünyesine giren ilkelerin başında ihtiyat ilkesi gelmektedir. İhtiyat ilkesi potansiyel zarar mevcut olduğunda ve bununla birlikte bilimsel belirsizliğin var olması halinde zararı önlemek için tedbir alınması gereğini içermektedir. ${ }^{46}$ $\mathrm{Bu}$ anlaşmanın kabulünden sonra AB'de yasal mevzuat “ihtiyat ilkesi” göz önüne alınarak oluşturulmaya başlandı. ${ }^{47}$ Ayrıca bunun yanında AB'de GDO’lara ilişkin mevzuat düzenlenirken halkın etik değerleri de ön planda tutulmuştur. ${ }^{48}$ İhtiyat ilkesinin bir getirisi olarak GDO’lu ürünlerin, ilaçların vb. etkilerinin ne olabileceği henüz kesin olarak bilinmemektedir. İşte bu bilinmezlik endişelere yol açtığından AB'de GDO'lara ilişkin düzenlemeler çok katı kurallara tabidir.

$\mathrm{AB}$ üyesi ülkeler arasında genetiği değiştirilmiş organizmalarla ilgili olarak ilk defa yasal düzenlemeye giden ülke Danimarka olmuştur. ${ }^{49}$ GDO’larla ilgili çıkarılan yönergelerin öncelikli amacı AB üyesi ülkeler arasında GDO’lara ilişkin uygulamayı bir düzene sokmak, uygulama birliği yaratmaktı. ${ }^{50}$ Böylece tüm üye ülkelerde GDO'ların potansiyel zararlı etkilerine karşı ihtiyat ilkesine göre ortak önlemler alınabilecektir. Ayrıca bu düzenlemelerin amacı insan ve hayvan sağlığını korumanın yanı sıra üye ülkeler arasında rekabeti ve GDO'ların ticaretine ilişkin kuralları düzenlemekti. ${ }^{51}$

GDO’larla ilgili yönergeler Genetiği Değiştirilmiş Mikroorganizmaların Kapalı SistemlerdeKullanımınaİlişkinKonseyYönergesi(98/81/EG) veGenetiğiDeğiştirilmiş Organizmaların Çevreye Bilinçli Salınımına İlişkin Avrupa Parlementosu Konsey Yönergesidir(2001/18/EG). Bu yönergeler Avrupa Topluluğu Anlaşmasının 249. maddesinin 3. fikrası gereğince üye ülkelerde doğrudan uygulanma kabiliyetine sahip olmayıp üye ülkelerin ulusal makamlarınca iç hukuka aktarılacaktır. ${ }^{52}$ Bunlardan başka GDO’ların sınıraşan hareketlerine ilişkin tüzük, GDO'ların İzlenebilirliği, Etiketlenmesine İlişkin Tüzük ve Genetiği Değiştirilmiş Gıda ve Yemlere İlişkin Tüzük temel düzenlemelerdir. Bu tüzükler ise Avrupa Topluluğu Anlaşması'nın 249. maddesinin 2. fikrası gereğince üye ülkelerde doğrudan uygulanacaktır.

AB'de GDO'lara ilişkin mevzuatın uygulanmasında yetkili iki kurum Avrupa

45 “T.C. AB Bakanlığı, AB’nin Çevre Politikası”, erişim 20 Ocak, 2020, https://www.ab.gov.tr/92.html.

46 İhtiyat ilkesi ile ilgili ayrıntılı bilgi için bkz. Zehra Gizem Ateş, "Biyogüvenlik Kanunu Çerçevesinde Hukuki Sorumluluk", Doktora Tezi, İstanbul Kültür Üniversitesi Lisansüstü Eğitim Enstitüsü Özel Hukuk Anabilim, 2020, s.7 vd.

47 Topal, Biyogüvenlik ve Biyoteknoloji, s.211; Yılmaz, "Bitkisel Üretimde”, s.155.

48 Topal, Biyogüvenlik ve Biyoteknoloji, s.211.

49 Mustafa Fadıl Yıldırım, Gen Teknik Uygulamalardan Doğan Hukuki Sorumluluk, Ankara: Engin Yayınevi, 2008, s.62; Güneş, "Genetiği Değiştirilmiş̧", s.63.

50 Yildırım, Gen Teknik, s.62; Güneş, "Genetiği Değiştirilmiş", s.63.

51Oğuzlar, Genetiği Değiştirilmiş, s.57; Yıldırım, Gen Teknik, s.63; Güneş, "Genetiği Değiştirilmiş", s.63.

52"European Union Consolidated Versions of the Treaty on European Union and of the Treaty Establishing the European Community", Offical Journal of the European Union, C321 E/1, 29.12.2006, http://www.bumko.gov.tr/ Eklenti/2841,maastrichtconsolidateenpdf.pdf?0, (erişim 22.01.2020) 
Komisyonu ve Avrupa Gıda Güvenilirliği Otoritesi'dir (EFSA-European Food Safety Authority). ${ }^{53}$ EFSA, GDO'lu ürünler, yemler, gida maddeleri üzerinde risk değerlendirmesi ve risk yönetimi yapıp bunların insan sağlı̆̆ı üzerindeki etkilerini araştıran bağımsız bir kuruluştur. ${ }^{54} \mathrm{Bu}$ değerlendirme "Genetiği Değiştirilmiş Bitkilerden Elde Edilen Gıda ve Yemlerin Risk Değerlendirme Rehberi” esas alınarak yapılmaktadır. ${ }^{55}$ Buna göre EFSA, genetiği değiştirilmiş tohumlardan elde edilen ürünlerle geleneksel yöntemlerle elde edilen ürünleri karşılaştırıp sonuçlarda risk analizi yapmaktadır. Risk değerlendirmesi uzmanlaşmış bilimsel komiteler yardımıla yapıldıktan sonra EFSA tüketicileri elde edilen sonuçlar konusunda bilgilendirir ve üye ülke örgütleri ile birlikte gıda güvenliğine ilişkin öncelikler belirlenir, gerekli uyarılar yapılır. ${ }^{56} \mathrm{AB}$ Komisyonu ise GDO’ların sosyo-ekonomik açıdan değerlendirmesini yapmaktadır. ${ }^{57}$

\section{Genetiği Değiştirilmiş Mikroorganizmaların Kapalı Kullanımı}

Genetiği değiştirilmiş mikroorganizmaların kapalı alanda kullanımına ilişkin 90/219 sayılı AB yönergesi, 98/81 sayılı yönerge ile değiştirilmiş ve son halini almıştır. Buna göre genetiği değiştirilmiş organizmaların kapalı kullanımı, bunların üretimi, saklanması, taşınması, transferi, imha edilmesi sırasında çevre ve nüfus ile fiziksel temasını engellemek için yapılan özel kısıtlayıcı önlemleri kapsamaktadır. ${ }^{58}$

Yönergenin kapsamına genetiği değiştirilmiş mikroorganizmalar girmektedir. Başka bir deyişle genetiği değiştirilmiş bitkiler, hayvanlar bu yönergenin kapsamına girmemektedir. Yönergede genetiği değiştirilmiş mikroorganizmalar şu şekilde tanımlanmaktadır: Genetik yapısı doğal yollarla oluşamayacak şekilde harici yolarla meydana getirilmiş organizmalardır. ${ }^{59}$

Yönergenin 5. maddesinin 1. fıkrası üye devletleri, genetiği değiştirilmiş organizmaların kapalı kullanımı sırasında bunların çevre ve insan sağlığı üzerinde yaratabileceği olumsuz etkilere karşı önlem almakla yükümlü tutmaktadır. ${ }^{60}$ Üye devletler bu amaca varılabilmesi için, kapalı kullanım sırasında oluşabilecek zararlara karşı risk değerlendirmesi yapacaklardır. ${ }^{61} \mathrm{Bu}$ düzenlemelerden yönergenin amacının genetiği değiştirilmiş organizmaların kapalı kullanımı sırasında çevre ve insan sağlığı üzerinde oluşabilecek risklere karşı tedbir alınması gerekliliği olduğu anlaşılmaktadır. ${ }^{62}$

\footnotetext{
53 Sayıt Mahmut Erdoğan, "Dünyada GDO Mevzuatı, Ticareti ve Uygulamalarının Karşılaştırılması ve Türkiye”, AB Uzmanlık Tezi, T.C. Gıda, Tarım ve Hayvancılık Bakanlığı, 2015, s.25; Mutlu, "Piyasada Satışa”, s.31. 54 Mark A. Pollack ve Gregory C. Shaffer, When Cooperation Fails, the International Law and Politics of Genetically Modified Foods, Oxford: Oxford University Press, 2009, s.237.

55 Erdoğan, "Dünyada GDO”, s.36.

56 Pollack ve Shaffer, When Cooperation, s.237

57 Erdoğan, “Dünyada GDO”, s.36.

58 “Council Directive 98/81/EEC, Art. 2-c", http://eur-lex.europa.eu/LexUriServ/LexUriServ. do?uri=OJ:L:1998:330:0013:0031:EN:PDF, (erişim 20.01.2020)

59 “Council Directive 98/81/EEC, Art. 2-b".

60 "Council Directive 98/81/EEC, Art. 5/1".

61"Council Directive 98/81/EEC, Art.5/2".

62Mutlu, "Piyasada Satışa”, s.30; Güneş, “Genetiği Değiştirilmiş”, s.65; Oğuzlar, Genetiği Değisştirilmiş, s.59.
} 
Yönergenin 7-11. maddelerinde ${ }^{63}$ ise genetiği değiştirilmiş organizmanın kapalı alanda kullanımı için izin usulü yer almaktadır. Organizmayı kullanacak olan muhatap risk değerlendirmesini yaptıktan sonra ilgili kurum değerlendirme sonuçlarını inceler. Gerekirse kamuoyunun görüşünü de alarak genetiği değiştirilmiş organizmanın verebileceği potansiyel riskler için tedbir alınmasına karar verir. Alınacak tedbirler organizmanın ne kadar riskli olduğuna bağlıdır.

Genetiği değiştirilmiş organizmaları kullanacak olan kişi risk altında olan, bu kullanımdan zarar görebilecek kişileri ve ilgili makamları konuyla ilgili olarak bilgilendirmeli, acil durum eylem planı oluşturulmalı ve zarar meydana geldiği anda Avrupa Komisyonu ve yetkili makamlar bilgilendirilmelidir. ${ }^{64}$

\section{Genetiği Değiştirilmiş Organizmaların Çevreye Kasıtlı Bırakılması}

Genetiği değiştirilmiş organizmaların çevreye kasıtlı salımına ilişkin olarak 90/220/ EEC sayılı yönerge 12 Mart 2001 tarihli 2001/18/EC sayılı yönerge ile değiştirilmiştir. Üye ülkeler, etiketleme ve GDO içeren ürünlerin ülkelerde kabul edileceği eşik konularında daha sıkı kısitlamalar getirilmesini istediler. ${ }^{65}$ Ancak bu konuda üye ülkeler arasında görüş birliği yoktu. Avusturya ve Lüksemburg gibi bazı ülkeler topraklarında GDO içeren hiçbir ürünün yetiştirilmesini kabul etmezken, Almanya ve İngiltere gibi bazı ülkeler de GDO'lara karşı olumlu ve olumsuz görüşler arasında ikiye bölünmüş durumdayd $1 .{ }^{66}$ Nihayet üye devletlerden oluşan uzlaşma komisyonu kurularak çözüm sağlandı ve 12 Mart 2001'de yönergenin son hali kabul edildi. ${ }^{67}$

$\mathrm{Bu}$ değiş̧iklikle birlik düzenlemelerinin teknolojik gelişmelere uyumlu hale gelmesi, üye ülkelerin risk değerlendirmelerine ilişkin uygulamalarının eşitlenmesi ve izin usullerini şeffaf hale getirerek kamuoyunun karar alma sürecine dahil edilmesi amaçlanmıştır. ${ }^{68}$ Yapılan değişikliğe rağmen yönergenin otoriter prosedürü ve çevre ve insan sağlı̆̆ının korunması amacı muhafaza edilmiştir. ${ }^{69}$ Anahtar kelimeleri değişen yönerge, ayrıca risk değerlendirmesine ilişkin ayrıntılı prensipleri, uygulamalar hakkında kamuoyunun görüşünün alınmasını, genetiği değiştirilmiş organizmaların çevre ve insan sağlı̆̆ 1 üzerinde yaratabileceği uzun vadeli etkilerinin ve etik kaygıların değerlendirme sürecine dahil edilmesini ve uygulamayı yapacak olan üye devletin uygulama öncesinde onaya sunacağ 1 risk değerlendirmesinin yapılmasını içermektedir. ${ }^{70}$

Genetiği değiştirilmiş organizmaların çevreye kasıtlı bırakılması, nüfus ve çevre ile bu organizmaların etkileşime geçmesi ve bunun için önlem alınması gerekliliğini

63 "Council Directive 98/81/EEC, Art. 7-11".

64 "Council Directive 98/81/EEC, Art. 14-19".

65 Pollack ve Shaffer, When Cooperation, s.239.

66 Pollack ve Shaffer, When Cooperation, s.239.

67Pollack ve Shaffer, When Cooperation, s.240.

68 Güneş, "Genetiği Değiştirilmiş”, s.67.

69 Jacqueline Peel, Rebecca Nelson ve Lee Godden, "GMO Trade Wars: The Submissions in the EC-GMO Dispute in the WTO”, Melbourne Journal of International Law, 6 (2005), s.11, http://law.unimelb.edu.au/_data/assets/ pdf_file/0011/1681148/Peel,-Nelson-and-Godden.pdf. (Erişim 20.01.2020).

70Peel Nelson ve Godden, “GMO Trade”, s.11. 
ifade eder. ${ }^{71}$ Yönergenin "amaç" başlıklı 1. maddesine göre yönergenin amacı, ihtiyat ilkesine bağlı kalarak, genetiği değiştirilmiş organizmaların kasıtlı olarak çevreye bırakılması, üye ülkeler arasında piyasaya sürülmesi durumunda çevre ve insan sağlığını korumak ve üye ülkelerin bu konudaki hukuki düzenlemelerinin uyumlu hale getirilmesidir. ${ }^{72}$ Yönergenin 2. maddesi tanımları verirken 3. maddesi ise muafiyetlerden bahsetmektedir. "Genel yükümlülükler” başlıklı 4. maddesinde ise genetiği değiştirilmiş organizmaların çevreye kasıtlı salınması ve piyasaya sürülmesi durumunda üye devletlerin ihtiyat ilkesine bağlı kalarak önlem alması gerektiğini belirtmektedir. ${ }^{73}$

Çevreye kasıtlı bırakmanın kapsamına genetiği değiştirilmiş organizmaların üretim vs. amaçlı bırakılması, hem de piyasaya sürülmesi girmektedir. Bu nedenle yönerge, hem GDO’ların çevreye kasıtlı salınımına hem de piyasaya sürülmesine ilişkin hükümler içermektedir. Bu nedenle yönergenin içeriğini iki başlık halinde incelemekte fayda vardır.

\section{Genetiği Değiştirilmiş Organizmaların Deneysel Amaçlarla Çevreye Bırakılması}

2001/18/EC sayılı yönergenin B bölümünde 5-11. maddeler, GDO’ların piyasaya sürülmesinden başka sebeplerle kasıtlı olarak çevreye bırakılmasına ilişkin düzenlemeler içerir. Burada kastedilen GDO’ların araştırma, geliştirme, tohum çoğaltma, risk değerlendirme, deneyler, biyoteknolojik çalışmalar vb. sebeplerle çevreye birakılmasıdır. ${ }^{74}$

Deneysel amaçlarla çevreye bırakma, kapalı kullanımın bir adım ilerisini teşkil etmektedir. Ancak burada çevreye bırakılan organizmalar diğer canlı türleriyle etkileşime geçerek doğal dengeyi değiştirebileceğinden daha ağır izin yöntemleri öngörülmektedir. ${ }^{75}$ Yönergede belirtilen izin usulü salınımın gerçekleşeceği üye devletin yetkili makamına bildirimde bulunulmasıyla başlar. Bu bildirimin içeriğinde yer alması gereken bilgiler yönergenin EK-III A ve B bölümlerinde belirtilmiştir. ${ }^{76}$

71 Oğuzlar, Genetiği Değiştirilmiş, s.61.

72 "Directive 2001/18/EC of the European Parliament and of the Council of 12 March 2001 on the Deliberate Release on the Environment of Genetically Modified Organisms and Repealing Council Directive 90/220/EEC, Article 1", http://eur-lex.europa.eu/resource.html?uri=cellar:303dd4fa-07a8-4d20-86a8-0baaf0518d22.0004.02/ DOC_1\&format=PDF, (erişim 20.01.2020).

73 "Directive 2001/18/EC Of The European Parliament and of the Council of 12 March 2001 on the Deliberate Release on the Environment of Genetically Modified Organisms and Repealing Council Directive 90/220/EEC, Article 4".

74"2003/701/EC, Comission Decision of 29 September 2003 establishing pursuant to directive 2001/18/EC Of The European Parliament and Of The Council a format for presenting the results of the deliberate release into the environment of genetically modified highed plants for purposes other than placing on the market, Annex Art. 5", http://eur-lex.europa.eu/LexUriServ/LexUriServ.

do?uri=OJ:L:2003:254:0021:0028:EN:PDF, (erişim 20.01.2020); Oğuzlar, Genetiği Değiştirilmiş, s.62; Güneş,

"Genetiği Değiştirilmiş", s.68.

75 Ylldırım, Gen Teknik, s.65.

76 Annex III A, Information Required in Notifications Concerning Releases of Genetically Modified Organisms Other than Higher Plants, Annex III B, Information Required in Notifications Concerning Releases of Genetically Modified Higher Plants (GMHPs), http://eur-lex.europa.eu/resource.html?uri=cellar:303dd4fa-07a8-4d2086a8-0baaf0518d22. 0004.02/DOC 1\& format=PDF, (erişim 20.01.2020). 
Bildirimi yapan üye devlet ayrıca salınımı yapılacak GDO ile ilgili olarak risk değerlendirmesi yapıp GDO’nun içeriği, çevre ve insan sağlığına etkileri, çevreyle etkileşiminin olası sonuçları hakkında ilgili devlete bilgi vermekle yükümlüdür. ${ }^{77}$ Bildirimi alan devlet bu bilgileri değerlendirip izin verip vermemekte serbesttir.

Bildirimin alınmasının ardından bildirimi alan üye devlet ile diğer üye devletle ve komisyon arasındaki bilgi alışverişi süreci başlamış olur. Bildirimi alan devlet bildirimin özetini, aldığ 1 tarihten itibaren 30 gün içinde komisyona gönderecektir. ${ }^{78}$ Komisyon da bildirimin kendisine ulaştığı tarihten itibaren 30 gün içinde bildirimin özetini diğer üye devletlerle paylaşacaktır. ${ }^{79}$ Yönergede yapılan iki önemli değişiklik 9 ve 11. maddelerde belirtilmiştir. Üye devletler bilgi değişim süreci hakkında ve B bölümünde belirtilen ülkede salınımı yapılacak GDO'lar hakkında kamuoyunu bilgilendirmelidir. ${ }^{80}$ Bildirimi alan üye devlet kendisine bildirimin özeti yerine tam metnin gönderilmesini de isteyebilir. ${ }^{81}$

Bilgi değişim süreci sona erdikten sonra ilgili devletin yetkili makamı bildirimin alınmasından itibaren 90 gün içinde başvurucu devlete GDO’nun ülkesinde deneysel amaçla serbest bırakılmasına izin verip vermediğini yazılı olarak açıklamakla yükümlüdür. ${ }^{82} \mathrm{Bu}$ bildirimde ilgili devlet salınıma izin verebileceği gibi kendisine yapılan bildirimin yönergeye uygun olmadığını belirterek reddetme hakkına da sahiptir.

GDO'nun deneysel amaçla serbest bırakılmasına izin verilmesinin ardından ilgili üye devletler şartların takipçisi olacaklardır. Çevreye serbest bırakılan organizmaların çevre ve insan sağllğ 1 üzerinde risk yaratması, beklenmedik bir değişimin ortaya çıkması ya da GDO ile ilgili yeni bilgilerin elde edilmesi durumunda bildirimde bulunan yetkili kuruma haber vermekle, çevre ve insan sağlı̆̆ını koruyucu tedbirler almakla ve bildirimde yer alan tedbirleri yeniden gözden geçirmekle yükümlüdür. ${ }^{83}$ Yetkili kurum durumun değişikliğini değerlendirip kamuoyunun bilgisine sunar ve bildirimde bulunan devletten durumun özelliğine göre şartları değiştirmesini, serbest bırakmayı ertelemesini veya sona erdirmesini isteyebilir. ${ }^{84}$

\section{Genetiği Değiştirilmiş Organizmaların Piyasaya Sürülmesi}

Genetiği değiştirilmiş organizmaların piyasaya sürülmesine ilişkin kurallar, diğer düzenlemelerin aksine tüm üye devletleri etkileyecektir. Çünkü yönergenin serbest dolaşım başlıklı 22. maddesine göre üye devletler yönergede izin verilen organizmaların piyasaya sürülmesini yasaklayan, kısıtlayan veya engelleyen düzenlemeler yapamazlar. Bu nedenle genetiği değiștirilmiş organizmaların piyasaya sürülmesine ilişkin kurallar daha da sıkı koşullara tabi tutulmuştur. Bu kurallar

77 "Directive 2001/18/EC, Art. 6".

78 "Directive 2001/18/EC, Art. 11/1"

79 "Directive 2001/18/EC, Art. 11/2".

80 "Directive 2001/18/EC, Art. 9".

81 "Directive 2001/18/EC, Art. 11".

82 "Directive 2001/18/EC, Art. 6/5".

83 "Directive 2001/18/EC, Art. 11/1".

84 "Directive 2001/18/EC, Art. 11/2". 
yönergenin Cbölümünde (md. 12-24) yer almaktadır. Yönergenin kapsamına genetiği değiştirilmiş organizmalar ve bu organizmaları içeren ürünler girmektedir. Ancak genetiği değiştirilmiş organizmalardan türetilmiş ürünler yönerge kapsamında değildir. Çünkü bu ürünler Genetiği Değiştirilmiş Gıda ve Yemlere İlişkin Tüzük ve Yeni Gıda Tüzüğü kapsamındadır. ${ }^{85}$

Öncelikle GDO’nun piyasaya ilk kez sürüleceği devlete bildirimde bulunulur. ${ }^{86}$ Bildirimi alan devlet GDO'lara ilişkin değerlendirme raporunu 90 gün içinde hazırlar. ${ }^{87}$ Ayrıca bildirimi alan devlet olumsuz görüş taşımıyorsa bu değerlendirmeyi komisyona, komisyon da diğer üye devletlere bildirir. ${ }^{88}$ Diğer üye devletler ve komisyon, bildirimin kendilerine ulaşmasından itibaren 60 gün içinde ek bilgi talebinde bulunabilir, görüşlerini veya itirazlarını bildirebilir. ${ }^{89}$ Diğer üye devletler ve komisyon itiraz etmezse gerekli izin verilir. Eğer itiraz ederlerse veya komisyon gerekli görürse, genetiği değiştirilmiş organizmanın çevre ve insan sağlığı üzerindeki risklerinin belirlenmesi için bilimsel komiteye başvurulur. ${ }^{90}$ Bilimsel komitenin kararı doğrultusunda tüm üye ülkeler bir araya gelerek karar verilir.

GDO’nun piyasaya sürülmesine ilişkin karar alındığında bu durum karar alındıktan itibaren 30 gün içinde diğer üye devletlere bildirilir. ${ }^{91} \mathrm{Bu}$ izin GDO'nun veya GDO içeren ürünün birlik çapında kullanımını sağlar. ${ }^{92}$ İzin en fazla 10 yıllık süre için verilebilir..$^{93}$

Genetiği değiştirilmiş organizmalar piyasaya sürüldükten sonra üye devletler bazı şartlarla birtakım önlemler alabilirler. Üye devletlerin yönergeye göre izin verilmiş GDO'lar hakkında kural olarak yasaklayıcı veya kısıtlayıcı önlem alamayacaklarını, bunun dabirlikiçinde serbest dolaşımın gereği olduğunu belirtmiştik. Ancak 2001/18/ EC sayılı yönergeye göre 90/220 sayılı yönergeden farklı olarak üye devletler, yapılan risk değerlendirmesinde veya GDO’nun piyasaya sürülmesi durumunda GDO’nun çevre ve insan sağlığ 1 üzerinde risk yaratabileceğine ilişkin yeni veya ek bilimsel bulgu elde ederlerse, söz konusu GDO'yu ülkelerinde yasaklayabilir veya engelleyebilirler. ${ }^{94}$ Üye devletlerin bu engelleyemeye dair karar almaları keyfi olmamalıdır. Böyle bir karar alan üye devlet bu kararı gerekçeleriyle birlikte komisyona ve diğer üye devletlere bildirmekle yükümlüdür. ${ }^{95}$ Kararı alan devlet gerekçesinde GDO'nun çevre ve insan sağllğı üzerinde hangi riskleri oluşturduğunu, bu konuda elde edilen yeni veya ek bilgiyi, durumun telafi edilmesi için yapılması gerekenleri bulundurmalıdır.

Piyasaya sürülmesine izin verilen GDO’nun denetimi için izin verildikten sonra

85 Güneş, “Genetiği Değiştirilmiş", s.69; Oğuzlar, Genetiği Değişsirilmiş, s.65-66.

86 "Directive 2001/18/EC, Art. 13".

87 "Directive 2001/18/EC, Art. 14".

88 "Directive 2001/18/EC, Art. 13/1".

89 "Directive 2001/18/EC, Art. 15/1".

90 "Directive 2001/18/EC, Art. 28".

91 "Directive 2001/18/EC, Art. 30".

92 Oğuzlar, Genetiği Değiştirilmiş, s.68.

93 "Directive 2001/18/EC, Art. 15/4".

94 Bu önlemlere "safeguard clause" denilmektedir, "Directive2001/18/EC, Art. 23/1".

95 Directive 2001/18/EC, Art. 23/1". 
bildirimde bulunan devlet tarafından gözetim planı hazırlanır. ${ }^{96}$ Gözetim planında yer alacak unsurlar yönergenin Ek VII ${ }^{97}$ bölümünde belirtilmektedir. Gözetim planının amacı GDO'ların varlığının tahmin edilen olumsuz etkilerinin teyit edilmesi ve çevre ve insan sağlığı üzerinde daha önceden öngörülmemiş etkilerinin belirlenmesi olarak açıklanmıştır. ${ }^{98}$ Böyle etkilerin görülmesi durumunda bildirimde bulunan devlet yetkili kurumu derhal bilgilendirmekle ve çevre ve insan sağlığını korumak için gereken önlemleri almakla yükümlüdür. ${ }^{99}$ Yetkili kurum durumu komisyona ve diğer üye devletlere bildirmekle yükümlüdür. ${ }^{100}$

\section{Genetiği Değiştirilmiş Gıda ve Yemler}

Genetiği değiştirilmiş organizmaların piyasaya sürülmesine ilişkin 2001/18 sayılı yönerge birlik çapında yetersiz bulunarak eleştiriliyordu. Bunun sebebi daha sıkı bir düzenlemeden yoksun olunan bir ortamda hala ulusal koruma öngörmesi ve hakiki yasal gecikmede 1 srarcı olmasıyd ${ }^{101}$ Bu görüşü paylaşan ülkeler özelikle Avusturya, Danimarka, Fransa, Yunanistan, İtalya ve Lüksemburg'du. ${ }^{102}$

$\mathrm{Bu}$ eleştirel bakış üzerine Komisyon yeni bir tüzük için öneride bulundu. Daha sonra GDO’lara ilişkin daha sıkı bir düzenleme getiren 1829/2003 sayılı tüzük yürürlüğe girmiştir. Bu tüzük ile piyasaya sürüm öncesi değerlendirme ve izin süreci uzatılmış ve detaylandırılmıştır. İzin sürecine Avrupa Gıda Güvenliği Örgütü (EFSA) ve üye devletlerin temsilcilerinden oluşan Gıda Zinciri ve Hayvan Sağlığı Daimi Komitesi dahil edilmiştir.

Tüzüğün öngördüğü izin usulü, genetiği değiştirilmiş gıda ürünü ya da yemi piyasaya sürmek isteyen kişinin, ürünün pazarlanacağı yerdeki yetkili kuruma başvuru yapmasıyla başlar. ${ }^{103}$ Başvuruda genetiği değiştirilmiş ürünün çevre ve insan sağlığına karşı risk taşımadığına ilişkin değerlendirme, ürünün üretim metodu, tüketiciler için kullanım önerisi ve etiketleme önerisi gibi bilgiler yer alır. ${ }^{104}$ Piyasaya sürülecek ürünler genetiği değiştirilmiş organizmadan meydana geliyorsa ya da genetiği değiştirilmiş organizma içeriyorsa, 2001/18 sayılı yönergede yer alan şartlara uygun olarak çevre ve insan sağlı̆̆ üzerinde risk değerlendirmesi yapılmalı, ayrıca yine 2001/18 sayılı yönergede sözü geçen gözetim planı hazırlanmalıdır. ${ }^{105}$

96 “2002/811/EC Council Decision of 3 October 2002 Establishing Guidance Notes Supplementing Annex VII to Directive 2001/18/EC of the European Parliament and of the Council on the Deliberate Release", The Environment of Genetically Modified Organisms and Repealing Council Directive 90/220 EC, http://eur-lex.europa.eu/legalcontent/EN/TXT/PDF/?uri=CELEX: 32002 D0811\&from=en, (erişim 20.01.2020).

97 Directive 2001/18/EC, Annex VII".

98 Directive 2001/18/EC, Annex VII, A".

99 Directive 2001/18/EC, Art. 20/2".

100 Directive 2001/18/EC, Art. 20/3".

101 Pollack ve Shaffer, When Cooperation, s.240.

102Pollack ve Shaffer, When Cooperation, s.240.

103"Regulation (EC) No 1829/2003 of the European Parliament and of the Council of 22 September 2003 on Genetically Modified Food and Feed, Art 5/2- Art. 17/2”, http://eur-lex.europa.eu/LexUriServ/LexUriServ. do?uri=OJ:L:2003:268:0001:0023:EN:PDF,

(erișim 20.01.2020)

104 "Regulation (EC) 1829/2003, Art. 5/3-Art. 17/3".

105 “ Regulation (EC) 1829/2003, Art. 5/5-Art. 17/5”. 
Ulusal yetkili kurum kendisine yapılan başvuruyu Avrupa Gıda Güvenliği Örgütüne bildirir. $\mathrm{O}$ da başvurunun içeriğini komisyon ve diğer üye devletlere bildirir. Böylece başvuruyu değerlendirme süreci başlar. EFSA başvuru hakkında görüşünü içeren değerlendirme raporunu 6 aylık süre içinde verir. ${ }^{106}$ Bundan sonra karar taslağını komisyon 3 ay içinde verecektir. ${ }^{107}$ EFSA'nın değerlendirme raporunu alan komisyon, GDO ile ilgili kararını açıklarken bu raporla bağlı değildir, rapordan bağımsız olarak karar verir. Komisyon karar verirken AB yasal düzenlemelerini ve sosyal, kültürel, çevresel diğer etkenleri göz önünde bulundurur. ${ }^{108}$

Komisyonun hazırladığı karar taslağı, üye devletlerden oluşan komiteye (Gıda Zinciri ve Hayvan Sağlığı Daimi Komitesi) sunulur. Komitenin de görüşüne göre karar alınır. Alınan karar AB Resmi Gazetesi'nde yayımlanır. ${ }^{109}$ Verilen izin en fazla 10 yıl için ve birlik çapında geçerli olur. ${ }^{110}$ Ayrıca izin verilen genetiği değiştirilmiş ürün, bunlara mahsus sicile kaydedilir ve sicil kamunun erişimine açık hale getirilir. ${ }^{111}$

İzin verildikten sonra buna bağlı olarak denetimler ve kontroller de yapılacaktır. Bu tüzük kapsamında koruma mekanizmasının geliştirilmiş olmasının sebebi, genetiği değiştirilmiş organizmaların olası risklerinin veya etkilerinin henüz kesinleşmemiş olmasıdır. Bu nedenle tüzüğe göre denetimler yapılacaktır.

Öncelikle izin sahibinin yerine getirmesi gereken denetim ve bildirim yükümlülükleri vardır. Genetiği değiştirilmiş organizmanın piyasaya sürülmesine dair izni alan, organizmanın çevre ve insan sağlığı üzerindeki etkilerini içeren rapor hazırlayıp komisyona sunmakla ve bu bildirimin içeriğini halka açı hale getirmekle yükümlüdür. ${ }^{112}$ İzin sahibi, genetiği değiştirilmiş organizmanın kullanım güvenliğini etkileyecek yeni bilimsel veya teknik bilginin ortaya çıkması durumunda komisyonu bilgilendirecek, ayrıca herhangi bir üye devlet organizmayı ülkesinde yasaklarsa bunu da derhal komisyona bildirecektir. ${ }^{113}$

Bunlardan başka izin verilen genetiği değiştirilmiş organizma hakkında bulgular veya veriler elde edilmesi durumunda komisyonun alacağ verilen organizmanın insan, hayvan sağlığı ve çevre üzerinde ciddi risklere sahip olduğu açıksa veya Avrupa Gıda Güvenliği Kurumu verilen iznin durdurulması veya değiştirilmesi yönünde görüş bildirirse, komisyon gerekli önlemleri almakla yükümlüdür. ${ }^{114}$ Üye devletler de bazı şartlar altında GDO’nun kullanımını kendi ülkelerinde yasaklayabilir veya kısıtlayabilirler. Ancak bu durumu komisyona derhal bildirmelidirler.

106 "Regulation (EC) 1829/2003, Art. 6/1-Art. 18/1".

107 "Regulation (EC) 1829/2003, Art. 7".

108 Oğuzlar, Genetiği Değiştirilmiş, s.78; "Regulation (EC) 1829/2003, Art. 7”.

109 "Regulation (EC) 1829/2003, Art. 7/4-Art. 19/4".

110 "Regulation (EC) 1829/2003, Art. 7/5-Art. 19/5".

111 "Regulation (EC) 1829/2003, Art. 28".

112 "Regulation (EC) 1829/2003, Art. 9/1-21/1".

113 "Regulation (EC) 1829/2003, Art. 9/3-21/3".

114 "Regulatrion (EC) 1829/2003, Art. 34". 


\section{Genetiği Değiştirilmiş Organizmaların İzlenebilirliği ve Etiketlenmesi}

$\mathrm{AB}$ düzenlemeleri içinde genetiği değiştirilmiş organizmaların izlenebilirliği ve etiketlenmesine ilişkin düzenlemelerin bir kısmı 1830/2003 sayılı tüzükte, bir kısmı da 1829/2003 sayılı tüzükte yer almaktadır. Bu tüzüklerde bulunan maddeler hem genetiği değiştirilmiş organizmadan oluşan ürünleri hem de genetiği değiştirilmiş organizma içeren ürünleri kapsamaktadır. Ayrıca sözü geçen 1830/2003 sayılı tüzük, $1829 / 2003$ sayılı tüzüğün ve 2001/18 sayılı yönergenin tamamlayıcısıdır ${ }^{115}$ ve 1830 ile 1829 sayılı tüzükler birlikte kabul edilmiştir.

Tüzügün amaçları GDO’ların veya GDO içeren ürünlerin çevre, insan ve hayvan sağlığı üzerinde taşıdığı riskleri tespit edip önlem alabilmek için izlenebilirlik ve etiketleme konusunda çerçeve oluşturmaktır. ${ }^{116}$ Böylece genetiği değiştirilmiş organizmalar veya bunları içeren ürünler piyasaya sürüldükten sonra takip edilmesi ve gerekirse piyasadan kaldırılması kolaylaşmış olacaktır. ${ }^{117}$

GDO’ların izlenebilirliği ile ilgili süreç üreticinin sorumluluğu ile başlamaktadır. Ürünün üreticisi içeriğinde GDO olduğunu veya ürünün GDO'dan oluştuğunu belirten kodlarla ${ }^{118}$ birlikte yazılı olarak ürünü alan işletmeciye aktarmakla yükümlüdür. ${ }^{119}$ Böylece bir ürünü satın alan kişi ya da kurumlar ürünün GDO içerdiğini veya GDO'dan oluştuğunu bileceklerdir. Hatta bu bilgilendirme sadece üretim ve ilk satış aşamasıyla sınırlı kalmamaktadır. Satış ve dağıtım zinciri içindeki her bir satıcı (veya sağlayıcı) ürünün içeriği hakkında diğerine yazılı bilgi vermeli ve ürünün kodunu iletmelidir. ${ }^{120} \mathrm{Bu}$ bilgileri alan her bir satıcı veya dağıtıc1, bu bilgileri ve ürünü satın aldığı veya sattığı kişilerin kaydını 5 yıl süreyle saklamakla yükümlüdür. ${ }^{121}$ Buradaki amaç üretimden itibaren satış ve dağıtımın her aşamasında ürünlerin izlenebilirliğinin sağlanmasıdır.

Etiketlemeye ilişkin uygulamalar ve düzenlemeler, en çok tartışılan ve birlik çapında en çok gündeme gelen düzenlemeler arasındadır. Bunlar da 1829/2003 ve 1830/2003 sayılı tüzüklerde yer almaktadır. GDO’ların ve GDO içeren ürünlerin etiketlenmesinin amacı tüketicinin bilgilendirilmesi ve bilinçli tercih yapmasının sağlanmasıdır. ${ }^{122}$ Aynı zamanda etiketleme, genetiği değiştirilmiş ürünün geleneksel benzerlerinden farklı olduğunu, besin değerlerini, toplum sağlığ 1 açısından etkilerini, etik ve dini kaygılara yol açabilecek olan niteliklerini belirtmelidir. ${ }^{123}$

Piyasadaki ürünler genetiği değiştirilmiş organizmadan elde edilmese veya genetiği değiştirilmiş organizma içermesi istenmese de, üretim, taşınma, işleme, depolama

115 Oğuzlar, Genetiği Değiştirilmiş, s.80.

116 "Regulation (EC) 1830/2003, Art. 1".

117 Oğuzlar, Genetiği Değiştirilmiş, s.80-81.

118 Burada sözü geçen kodlar, her bir ürün için ayrı ayrı hazırlanmış, GDO içermeyen diğer ürünlerden ayırt edilmesini sağlayan kodlardır, Regulation (EC) 65/2004, http://eur-lex.europa.eu/legal-content/EN/TXT/ $\mathrm{PDF} /$ ?uri=CELEX:32004R0065\&from $=\mathrm{EN}$, (erişim 19.01.2020)

119 "Regulation (EC) 1830/2003, Art. 4/1".

120 "Regulation (EC) $1830 / 2003$, Art. 4/2".

121 "Regulation (EC) 1830/2003, Art. 4/4".

122 "Regulation (EC) 1829/2003, Recital (20)".

123 "Regulation (EC) 1829/2003, Recital (22)". 
aşamasında bilinçli olmadan içeriğine GDO bulaşmış olabilir. İşte bu durumda GDO içeriği belli oranların altındaysa ürün etiketleme zorunluluğundan muaf tutulur. Tüzüğe göre geleneksel üründeki GDO kalıntısı \%0,9’u geçmiyorsa etiketlemeden muaf tutulacaktır. ${ }^{124}$ Muafiyetin uygulanabilmesi için karışmanın tesadüfi ve teknik açıdan kaçınılmaz olması, bunun yanında satıcının gereken tedbirleri almış olması gerekmektedir. ${ }^{125}$ Ayrıca tüzük GDO’nun birlik bilimsel risk değerlendirmesinde elverişli bulunabilmesi için \%0,5 oranında sıkı bir eşik öngörmektedir. ${ }^{126}$ Bununla birlikte tüzük üç yıl süreyle GDO’ların izlenmesini ve eğer çevrede kalıntı bırakmıyorsa, sıfır direnç gösteriyorsa kullanımına izin verilmesini öngörmektedir. ${ }^{127}$

\section{Sonuç}

Genetiği değiştirilmiş organizmalar, modern biyoteknolojik gelişmeler neticesinde hayatımıza girmiştir ve gıda, sağlık, endüstri başta olmak üzere birçok alanda kullanılmaktadır. İlk kez koyun Dolly'nin klonlanmasıyla başlayan gen aktarımı süreci daha sonra bitkilerin ve hayvanların genlerinin değiştirilmesi ile ilerlemiştir.

Dünyada çevreyi koruma bilincinin oluşması Stockholm Bildirgesi ile başlamış ve Cartagena Biyogüvenlik Protokolünün imzalanması ile devletlere insan, hayvan sağlığı ile çevre ve biyoçeşitliliğin korunması ve genetik kaynakların sürdürülebilir kullanımının sağlanması için iç hukuklarında düzenleme yapma yükümlülüğü getirilmiştir. Bunun üzerine AB'de GDO’lara ilişkin yönerge ve tüzükler kabul edilmiştir.

GDO’larla ilgili yönergeler Genetiği Değiştirilmiş Mikroorganizmaların Kapalı SistemlerdeKullanımınaİlişkinKonseyYönergesi(98/81/EG) veGenetiğiDeğiştirilmiş Organizmaların Çevreye Bilinçli Salınımına İlişkin Avrupa Parlementosu Konsey Yönergesidir(2001/18/EG). Bu yönergeler Avrupa Topluluğu Anlaşmasının 249. maddesinin 3. fikrası gereğince üye ülkelerde doğrudan uygulanma kabiliyetine sahip olmayıp üye ülkelerin ulusal makamlarınca iç hukuka aktarılacaktır. ${ }^{128}$ Bunlardan başka GDO'ların sınıraşan hareketlerine ilişkin tüzük, GDO'ların İzlenebilirliği, Etiketlenmesine İlişkin Tüzük ve Genetiği Değiştirilmiş Gıda ve Yemlere İlişkin Tüzük temel düzenlemelerdir. Bu tüzükler ise Avrupa Topluluğu Anlaşması̉nın 249. maddesinin 2. fikrası gereğince üye ülkelerde doğrudan uygulanacaktır.

$\mathrm{AB}$ üyesi devletler bu yönerge ve tüzüklere göre iç hukuklarında yasal düzenlemeler yapmışlardır. Örneğin Fransa'da Çevre Kanunu (Code De L'Environnement), Almanayàda Gen Teknik Kanunu genetiği değiştirilmiş organizmalara ilişkin düzenlemeler içermektedir. ${ }^{129}$

124 “Regulation (EC) 1829/2003, Art. 12/2, Art. 24/2; Regulation (EC) 1830/2003, Art. 4/7-8”.

125 "Regulation (EC) 1829/2003, Art. 12/3, 24/3".

126 Pollack ve Shaffer, When Cooperation, s.242.

127 Bu uygulama Nisan 2007'de yürürlüğe girmiştir. Ancak bu düzenlemeye ABD şiddetle karşı çıkmıştır. Çünkü bu sınırlama GDO'ların ticaretini engelleyen bir hükümdür, Pollack ve Shaffer, When Cooperation, s.242.

128 "European Union Consolidated Versions of the Treaty on European Union and of the Treaty Establishing the European Community", Offical Journal of the European Union, C321 E/1, 29.12.2006, http://www.bumko.gov. tr/Eklenti/2841,maastrichtconsolidateenpdf.pdf?0. (erişim 22.01.2020)

129 Bu kanunlarla ilgili ayrıntılı bilgi için bkz. Ateş, "Biyogüvenlik Kanunu”, s.50 vd. 
$A B$ yönergelerinin üye devletleri yasal düzenleme yapma, GDO’larla ilgili yeni bilgi edinildiğinde engelleme veya sınır getirme konusunda serbest bıraktığı için devletlerin farklı yasal düzenleme yapma yollarına gittikleri görülmektedir. Ancak tüm devletler birlik içerisinde serbest dolaşımı sağlama yükümlülügüunü de yerine getirme zorunluluğuna sahiptirler.

$\mathrm{AB}$ çatısı altında yönerge ve tüzüklerin kabul edilmesiyle birlik içinde yasal düzenleme birliği sağlanmış ve özellikle kamunun bilgi edinme hakkı ön plana çıkarılmıştır. Böylece GDO’larla ilgili olarak kamuoyunda oluşan olumsuz izlenimlerin de önüne geçilmiştir.

Cartagena Biyogüvenlik Protokolü’nü kabul etmiş olan Türkiye de AB uyum yasaları çerçevesinde genetiği değiştirilmiş organizmalarla ilgili yasal düzenleme yapma yoluna gitmiştir. Bu kapsamda düzenlemeler içeren 5977 sayılı Biyogüvenlik Kanunu 26.09.2010 tarihinde ülkemizde yürürlüğe girmiştir.

\section{Kaynakça}

Ateş, Zehra Gizem. "Biyogüvenlik Kanunu Çerçevesinde Hukuki Sorumluluk". Doktora Tezi, İstanbul Kültür Üniversitesi, 2020.

Atsan, Tecer ve Tuğba Ekrem Kaya. "Genetiği Değiştirilmiş Organizmaların (GDO) Tarım ve İnsan Sağlı̆̆ Dergisi. 22/ II (2008): 1-6.

Aydın, Halim. Sağlıklı Nesiller İçin Önce Sağlıklı Tohum. İstanbul: İstanbul Ticaret Odası Yayınları, 2012.

Bio technoogy, Economic and Wider Impacts, Organisation for Economic Co-Operation and Development (OECD), Paris: 1989.

Charles, Daniel. Lords of the Harvest. New York: Basic Books, 2002.

Çelik, Venhar ve Dilek Turgut-Balık. "Genetiği Değiştirilmiş Organizmalar (GDO)”. Erciyes Üniversitesi Fen Bilimleri Enstitüsü Dergisi. 23:1-2 (2007): 13-23. http// www.egecep.org.tr. (erişim 19.01.2020)

Çetiner, Selim. "Genetiği Değiştirilmiş Organizma Nedir? Sorular ve Yanıtlar 1-2”. http://research.sabanciuniv.edu/_Organizma_(GDO)_Nedir_Sor_I.pdf. (erişim 19.01.2020)

Demirkol, Kenan. GDO: Çağdaş Esaret. İstanbul: Kaynak Yayınları, 2010.

Denli, Muzaffer. Genetiği Değiştirilmiş Organizmalar (GDO). İstanbul: İstanbul Ticaret Odası, 2012.

Erdoğan, Sayıt Mahmut. "Dünyada GDO Mevzuatı, Ticareti ve Uygulamalarının Karşılaştırılması ve Türkiye”. AB Uzmanlık Tezi, T.C. Gıda, Tarım ve Hayvancılık Bakanlı̆̆ 1 Ankara, 2015.

Evenson, Robert ve Terri Raney. The Political Economy of Genetically Modified Foods. USA: Edward Edgar Publishing, 2007.

Franceskon, Silvia. "The New Directive 2001/18/EC on the Deliberate Release of Genetically Modified Organisms into the Enviroment: 
Changes and Perspectives". 10/3 (2001). http://onlinelibrary.wiley.com/ doi/10.1111/14679388.00290/epdf?r3_referer=wol\&tracking_action=preview_ click\&showcheckout=1\&purchase_referrer=www.google.com.tr\&purchase_ site_license. (erişim 20.01.2020)

Güneş, M. Ahmet. "Genetiği Değiştirilmiş Organizmalar ve Çevre Hukuku Uluslararası Düzenlemeler, Avrupa Birliği Hukuku ve Türkiyeddeki Mevcut Durum". İÜHFD. 56/2 (2008): 49-90.

Ho, Mae-Wan. Genetik Mühendisliği Rüya mı Kabus mu?. Çev., Emral Çakmak. İstanbul: Türkiye İş Bankası Kültür Yayınları, 2001.

Indur M. Goklany. "Applying the Precautionary Principle to Genetically Modified Crops". Genetically Modified Foods. Ed., Michael Ruse. David Castle. New York: Prometheus Books, 2002.

Kathiann M. Kowalski. The Debate over Genetically Engineered Food, Healthy or Harmful?. USA: Enslow Publishers, 2002.

Krueger, Roger. "Ag Biotech: Our Past and Our Future". Genetically Modified Organisms in Agriculture. Ed., Gerald C. Nelson. New York: Academic Press, 2001.

Mutlu, Şebnem. "Piyasada Satışa Sürülen Cips ve Gevreklerde GDO Varlığının Araştııılması". Yüksek Lisans Tezi, Namık Kemal Üniversitesi, 2006. http:// acikerisim. nku.edu.tr. (Erişim 19.01.2020)

Oğuzlar, Özlem. Genetiği Değiştirilmiş Organizmalara İlişkin Uluslararası ve Avrupa Birliğindeki Düzenlemeler. İstanbul: Galatasaray Üniversitesi Yayınları, 2009.

Özer, Kemal. Deccal Tabakta. İstanbul: Hayy Kitap, 2010.

Özgen Arun, Özge, Karlo Muratoğlu ve Funda Yılmaz Eker. “Genetiği Değiştirilmiş Organizmalar Kavramına Genel Bakış". İstanbul Üniversitesi Veteriner Fakültesi Dergisi. 41/1 (2015):113-123. https://www.researchgate.net/ publication/271208683 Genetigi_Degistirilmis_Organizmalar_Kavramina_ Genel_Bakis. (Erişim 19.01.2020).

Peel, Jacqueline, Rebecca Nelson ve Lee Godden. "GMO Trade Wars: The Submissions in the EC-GMO Dispute in the WTO". Melbourne Journal of International Law. 6 (2005). http://law.unimelb.edu.au/_data/assets/pdffile/0011/1681148/ Peel,Nelson-andGodden.pdf. (Erişim 20.01.2020)

Persley, Gabrielle J. ve James N. Siedow. "Application of Biotechnology to Crops Benefits and Risks". Genetically Modified Foods (GMO). Ed., Michael Ruse ve David Castle. Newyork: Prometheus Books, 2002.

Pollack, Mark A. ve Gregory C. Shaffer. When Cooperation Fails, the International Law and Politics of Genetically Modified Foods. Oxford: Oxford University Press, 2009.

Ronnie Cummins ve Ben Lilliston. Genetically Modified Food. New York: Marlowe\&Company, 2004.

Teitel, Martin ve Kimberly Wilson. Genetically Engineered Food, Changing the Nature of Nature. Canada: Park Street Press, 1999.

Topal, Şeminur. Biyogüvenlik ve Biyoteknoloji. İstanbul: Cem Ofset Matbaası, 2006. 
Treawas, Anthony."Much Food, Many Problems". Genetically Modified Foods. Ed., Michael Ruse, David Castle. New York: Prometheus Books, 2002.

Yıldırım, Mustafa Fadıl. Gen Teknik Uygulamalardan Doğan Hukuki Sorumluluk. Ankara: Engin Yayınevi, 2008.

Yılmaz, Funda. "Bitkisel Üretimde Genetiği Değiştirilmiş Organizmalar ve Ürünleri ile Biyogüvenlik”. Uzmanlık Tezi, T.C. Kalkınma Bakanlığı, 2014.

“Corpus Mevzuat ve İçtihat Bankası”. Erişim 16 Ocak, 2020. https://www.corpus. com.tr

"Fao (Food And Agriculture Organization Of The United Nations)". Erişim 19 Ocak, 2020. http://www.fao.org/biotechnology/en.

"https://www.bio.org/food-agricultural-biotechnology". Erişim 19 Ocak, 2020.

"World Health Organization (WHO)". Erişim 19 Ocak,2020. http://who.int.

“T.C. AB Bakanlığı, AB’nin Çevre Politikası”. Erişim 20 Ocak, 2020. https://www. ab.gov.tr/92.html.

"European Union Consolidated Versions of the Treaty on European Union and of the Treaty Establishing the European Community", Offical Journal of the European Union, C321 E/1, 29.12.2006, http://www.bumko.gov.tr/ Eklenti/2841,maastrichtconsolidateenpdf.pdf?0, (erişim 20.01.2020)

“Council Directive 98/81/EEC”., http://eurlex.europa.eu/LexUriServ/LexUriServ. do?uri=OJ:L:1998:330:0013:0031:EN:PDF. (erişim 20 Ocak 2020)

"Directive 2001/18/EC of the European Parliament and of the Council of 12 March 2001 on the Deliberate Release, on the Environment of Genetically Modified Organisms and Repealing Council Directive 90/220/EEC, Article 1". http:// eur-lex.europa.eu/resource.html?uri=cellar:303dd4fa-07a8-4d20-86a 80baaf0518d22.0004.02/DOC_1\&format=PDF. (erişim 20.01.2020)

"2003/701/EC, Comission Decision of 29 September 2003 Establishing Pursuant to Directive 2001/18/EC of The European Parliament and of the Council a Format for Presenting the Results of the Deliberate Release into the Environment of Genetically Modified Highed Plants for Purposes Other than Placing on the Market, Annex Art. 5". http://eur-lex.europa.eu/LexUriServ/ Lex Uri Serv. do?uri=OJ:L:2003:254:0021:0028:EN:PDF. (erişim 20.01.2020)

“2002/811/EC Council Decision of 3 October 2002 Establishing Guidance Notes Supplementing Annex VII to Directive 2001/18/EC of the European Parliament and of the Council on the Deliberate Release into the Environment of Genetically Modified Organisms and Repealing Council Directive 90/220 EC”. http://eur-lex. europa.eu/legal-content/EN/TXT/PDF/? uri=CELEX 32002D0811\&from=en. (erişim 20.01.2020)

"Regulation (EC) No 1829/2003 of the European Parliament and of the Council of 22 September 2003 on Genetically Modified Food and Feed". http://eurlex.europa. eu/LexUriServ/LexUriServ.do?uri=OJ:L:2003:268:0001:0023:EN:PDF. （erişim 20.01.2020)

"Regulation (EC) 1830/2003Of The European Parliament and of the Council of 
22 September 2003 Concerning the Traceability and Labelling of Genetically Modified Organisms and the Traceability of Food and Feed Products Produced from Genetically Modified Organisms and Amending Directive2001/18/ EC". https://eur-lex.europa.eu/legal-content/EN/TXT/PDF/?uri=CELEX: 32003R1830\&from=EN. (erişim 20.01.2020) 
İNSAN\&İNSAN, Y1//Year 7, Say1/Issue 24, Bahar/Spring 2020, 9-29

DOI: https://doi.org/10.29224/insanveinsan.678783

\title{
The Legal Arrangements of European Union Concerning The Genetically Modified Organisms
}

\author{
ZEHRA GIZEM ATEŞ
}

Abstract: Genetically modified organism (GMO) refers to as a new organism which is produced by transfering artificially gene to living beings' DNA structures. It is a well known fact that GMO is obtained throughout biotechnological studies. However, it can be argued that such production includes important risks for human health. Since the Maastrich Treaty in 1993, European Union (EU) has established legal arrangements against these health risks. By the same taken, one could analyse both regulations and directives concerning the problems of GMOs according to EU laws.

Anahtar Kelimeler: Genetically modified organisms, Health risks, European Unions directives and regulations. 